Gut, 1980, 21, 1017-1023

\title{
Allergic proctitis, a clinical and immunopathological entity
}

\author{
P C M ROSEKRANS, * C J L M MEIJER, A M VAN DER WAL, AND J LINDEMAN
}

From the Department of Gastroenterology and Pathology, University Medical Centre, Leiden, the Netherlands

SUMMARY Patients with isolated ulcerative proctitis form a heterogeneous group. Some may develop ulcerative colitis, others have a limited, benign disease. Twelve patients with isolated proctitis with a mean course of seven years were studied. All patients had a typical clinical picture consisting of a mild and intermittent course of the disease with the presenting symptom of rectal blood loss. At endoscopic examination the inflammatory process was limited to the rectal and distal sigmoid colonic mucosa with a clear upper border beyond which the mucosa of the sigmoid colon was normal. Histologically the mucosal biopsy specimens of the affected rectum resembled those of ulcerative colitis. However, in contrast with proctitis on the base of ulcerative colitis or Crohn's disease, immunoperoxidase staining revealed a markedly increased number of IgE containing cells in the lamina propria of rectal mucosa biopsies. As an IgE-mediated immune mechanism was considered to play a role in this type of proctitis, eight of the 12 patients were treated with oral administration of disodium cromoglycate (DSCG). All patients were improved by the drug. The remaining four patients with mild proctitis did not require treatment. We concluded that, in patients with isolated proctitis on clinical and immunopathological criteria, a group can be separated which responds to DSCG, a condition for which we suggest the name 'allergic proctitis'.

Isolated ulcerative proctitis can be defined as an inflammatory process of the rectal mucosa, without a specific cause, indistinguishable in appearance from that seen in ulcerative colitis, but with a clear upper border beyond which the mucosa of the sigmoid colon is normal by endoscopical vision and on $x$-ray examinination. ${ }^{1-3}$ Ulcerative proctitis may be a limited, relatively benign disease with few complications and a good prognosis. ${ }^{4}$ Some workers believe that diffuse ulcerative colitis and ulcerative proctitis are pathologically identical and consider proctitis a variant of ulcerative colitis. ${ }^{15}$ Other authors claim that proctitis is not the same as ulcerative colitis, primarily on the basis of clinical criteria. Many of the alleged differences could be explained by the extent of involvement. ${ }^{7}$ Rice-Oxley ${ }^{8}$ described proctitis as early ulcerative colitis.

Thus, the difference between isolated proctitis and ulcerative colitis appears to be the ultimate course

*Address for correspondence: P C M Rosekrans, Department of
Gastroenterology Academisch Ziekenhuis Leiden. 2333 AA Leiden, the Netherlands.

Received for publication 8 July 1980 of the disease rather than the presence of definite distinguishing features at the onset.

Systemic and local immunological abnormalities have been described in ulcerative colitis; however, data regarding the local immunological factors are conflicting. ${ }^{9-13}$ Immunological abnormalities have also been reported in isolated ulcerative proctitis. ${ }^{14} 15$

Wright and Truelove ${ }^{16}$ have suggested a possible pathogenetic role for milk in ulcerative colitis, as milk antibodies were found in many patients. Intradermal tests, especially to casein, were frequently positive in patients with ulcerative colitis, but the results did not differ from those found in healthy individuals. ${ }^{17}$

Large numbers of eosinophils have been reported in the rectal mucosa of patients with ulcerative colitis $^{18}$ and proctitis ${ }^{19}$, suggesting an allergic phenomenon in these disorders. The beneficial effect of disodium cromoglycate (DSCG) in patients with proctitis ${ }^{2021}$ and less clear-cut responses in patients with definite ulcerative colitis $^{22-24}$ suggests that different immunological mechanisms may be implicated in these diseases. 
In the present study we have examined the lamina propria cellular infiltrate of patients with localised ulcerative proctitis and compared this with the proctitis associated with ulcerative colitis and Crohn's disease. In contrast with patients with ulcerative colitis and Crohn's disease, patients with localised proctitis have an increased number of IgE containing cells in the rectal mucosa. We believe that this group of patients, with typical clinical and immunopathological features, form a separate entity.

\section{PATIENTS}

We examined 12 patients with symptoms of proctitis (average age 47 years; range 28-71 years). The presenting symptom in all cases was rectal bleeding, usually mild in degree and intermittent in appearance. In contrast with patients with diffuse colonic involvement no patient had rectal haemorrhage of sufficient severity to require blood replacement. A change in bowel habits was noted by most of the patients. Some had constipation, particularly if stool frequency is not considered to include small discharges of blood and mucopurulent material. True diarrhoea was present in only three patients with an average of not more than four stools a day. Two patients had abdominal cramps associated with tenesmus. The general health of all patients was good with absence of malaise, fever, or weight loss. At sigmoidoscopic examination these proctitis patients were selected from those with ulcerative colitis by the sharp limitation of the inflammatory process at, or just above the level of, the rectosigmoid junction. The sigmoidoscopic appearance is one of marked hyperaemia and oedema of the rectal mucosa, with superficial ulcerations. Multiple punctate haemorrhages may be visible and minor manipulation of the endoscope produces fresh bleeding.

Only one patient (no. 2) had a history of atopy. She had hay fever, eczema, and allergic rhinitis. Two patients had a family history of atopy (no. 8 hay fever, no. 9 flexural eczema).

For all patients the course was one of intermittent remission and exacerbation. The mean duration of the disease was seven years.

At least two mucosal biopsies were obtained from each patient. The first biopsy was taken from the rectum, approximately $7 \mathrm{~cm}$ from the anal margin, the second from the distal sigmoid colon at approximately $20 \mathrm{~cm}$.

Eight of the 12 patients were treated with DSCG †, $800 \mathrm{mg}$ orally ( $200 \mathrm{mg}$ qds, before meals and sleeping). The patients were instructed to open the capsule and to dissolve the DSCG powder in a glass of warm water. This was done to avoid the possibility tObtained from Fisons Ltd., Pharmaceutical Division, England. that DSCG might form aggregates with the gelatin in the upper gastrointestinal tract and not be well dispersed in the colon. The remaining four patients (nos. 5, 6, 11, and 12) with very mild proctitis or a spontaneous remission did not require treatment. Clinical data of the patients are summarised in Table 1.

All patients were treated with oral sulphasalazine. Three patients (nos. 1, 3, and 4) had topical corticosteroid treatment.

The immunohistochemical and morphometric biopsy findings from the 12 proctitis patients were compared with the rectal and colonic sigmoid biopsy specimens obtained from three groups of patients:

\section{Ulcerative colitis group}

There were 10 patients in this group with ulcerative colitis (average age 37 years; range $27-63$ years). The diagnosis was based on clinical, radiological, endoscopic, and histological findings. ${ }^{25}$ All patients in this group had severely inflamed mucosae in the sigmoid colon and rectum.

\section{Crohn's disease group}

Ten patients with Crohn's disease of the colon (average age 34; range 21-49 years) were included in this group. The history, radiological, endoscopic, and histological findings were typical of colonic localisation of Crohn's disease. In a number of cases there were only minor signs of inflammation in the distal colon because of the segmental nature of Crohn's disease.

\section{Control group}

The ten control patients in this group had no sign of colitis and colonoscopy was performed because of a single polyp or the irritable bowel syndrome (average age 35 years; range 19-64 years).

\section{Methods}

The sigmoidoscopic examinations were performed with an Olympus fibre colonoscope (CF1B) and an Olympus fibre sigmoidoscope (TCF 1S).

Rectal and sigmoid colonic mucosal biopsy specimens were fixed for three hours in a sublimate formaldehyde mixture. ${ }^{26}$ After fixation tissue samples were embedded in paraplast and $4 \mu \mathrm{m}$ thick sections were cut perpendicular to the luminal surface and mounted on glass slides. Sections were stained with haematoxylin and eosin (HE) and periodic acid Schiff (PAS) and specifically for IgA, IgG, IgM, IgD, and IgE heavy chains, using an indirect immunoperoxidase technique.

Rabbit antisera against IgA, IgG, and IgM heavy 


\begin{tabular}{|c|c|c|c|c|c|c|c|c|c|c|c|c|c|c|c|c|}
\hline$\dot{z}$ & 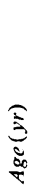 & ڤัँ & 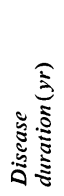 & $\frac{\grave{\delta}}{\bar{\delta}}$ & 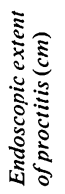 & 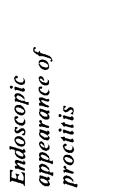 & $\begin{array}{l}= \\
\vdots \\
\vdots \\
\bar{\vdots} \\
\overline{0} \\
0 \\
0\end{array}$ & $\begin{array}{l}\vdots \\
\vdots \\
\vdots \\
\vdots \\
\vdots \\
\vdots \\
\vdots \\
\vdots \\
\vdots \\
0\end{array}$ & 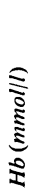 & 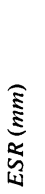 & 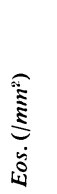 & 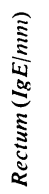 & 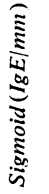 & 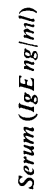 & 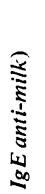 & 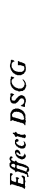 \\
\hline 1 & 57 & $\mathbf{F}$ & 16 & - & 20 & $\begin{array}{l}\text { Superficial } \\
\text { ulcerations }\end{array}$ & Normal & Intermittent & $9 \cdot 1$ & 17 & 190 & 31 & 12 & 53 & - & + \\
\hline 2 & 33 & $\mathbf{F}$ & 8 & $\begin{array}{l}\text { Hay fever, } \\
\text { rhinitis, } \\
\text { eczema }\end{array}$ & 15 & $\begin{array}{l}\text { Superficial } \\
\text { ulcerations }\end{array}$ & Normal & Intermittent & $8 \cdot 5$ & 10 & 50 & 34 & 9 & 30 & - & + \\
\hline 3 & 42 & $\mathbf{F}$ & 11 & - & 15 & $\begin{array}{l}\text { Superficial } \\
\text { ulcerations }\end{array}$ & Constip. & Intermittent & $8 \cdot 3$ & 3 & 50 & 16 & 7 & 21 & - & $t$ \\
\hline 4 & 50 & $\mathbf{M}$ & 7 & - & 8 & Ulcerations & Constip. & Intermittent & $8 \cdot 8$ & 8 & 180 & 35 & 9 & 82 & - & + \\
\hline 5 & 32 & $F$ & 4 & - & 10 & $\begin{array}{l}\text { Superficial } \\
\text { ulcerations }\end{array}$ & Normal & Intermittent & $7 \cdot 2$ & 16 & 100 & 29 & 6 & 80 & - & NT \\
\hline 6 & 28 & $\mathrm{~F}$ & 5 & - & 20 & $\begin{array}{l}\text { Superficial } \\
\text { ulcerations }\end{array}$ & Normal & Intermittent & $8 \cdot 4$ & 12 & 180 & 12 & 8 & 49 & - & NT \\
\hline 7 & 45 & $\mathbf{F}$ & 7 & - & 15 & $\begin{array}{l}\text { Hyperemia } \\
\text { oedema }\end{array}$ & Diarrhoea & Intermittent & $8 \cdot 2$ & 7 & 160 & 14 & 12 & 51 & - & + \\
\hline 8 & 42 & $\mathbf{M}$ & 11 & Family & 15 & $\begin{array}{l}\text { Hyperemia } \\
\text { oedema }\end{array}$ & Diarrhoea & Intermittent & $9 \cdot 4$ & 5 & 150 & 11 & 8 & 56 & - & + \\
\hline 9 & 70 & $\mathbf{M}$ & 1 & Family & 25 & $\begin{array}{l}\text { Superficial } \\
\text { ulcerations }\end{array}$ & Constip. & Intermittent & $9 \cdot 0$ & 13 & 50 & 26 & 12 & 20 & - & + \\
\hline 10 & 40 & $\mathrm{~F}$ & 3 & - & 10 & $\begin{array}{l}\text { Superficial } \\
\text { ulcerations }\end{array}$ & Diarrhoea & Intermittent & $8 \cdot 3$ & 14 & 220 & 32 & 6 & 24 & 一 & + \\
\hline 11 & 59 & $\mathrm{~F}$ & 2 & - & 20 & $\begin{array}{l}\text { Hyperemia } \\
\text { oedema }\end{array}$ & Normal & Intermittent & $8 \cdot 4$ & 10 & 170 & 19 & 9 & 72 & - & NT \\
\hline 12 & 71 & $\mathbf{F}$ & 8 & - & 20 & Oedema & Normal & Intermittent & $7 \cdot 5$ & 10 & 90 & 15 & 6 & 192 & - & NT \\
\hline
\end{tabular}

ESR : erythrocyte sedimentation rate, Westergren's method. Eos: peripheral blood eosinophils, normal count : 40-400/mm². Rectum and sigmoid $\mathrm{IgE} / \mathrm{mm}$ : number of IgE containing cells per mm mucosal length. Serum IgE: healthy controls $95 \%<500 \mathrm{ng} / \mathrm{ml}$. IgE anti-milk: RAST for specific IgE milk antibodies. Effect DSCG : + beneficial effect DSCG treatment: NT: no DSCG treatment.

chains were obtained from Dakopatts (Denmark) and rabbit antisera against IgD and IgE from the Central Laboratory of the Netherlands Red Cross Blood Transfusion Service, Amsterdam. The specificity of these antisera has been described before. ${ }^{27}$ Horse-radish peroxidase labelled goat anti-rabbit IgG was obtained from Miles (Yedah, Israel).

The method we used for morphometric study of the stained sections of rectal and colonic biopsy specimen was as follows:

Images of the sections were projected with a standard magnification of $\times \mathbf{2 0 0}$ on graph paper and drawings were made. The morphometric analysis of the drawings was done on a graphic tablet (Tektronix) interfaced to a laboratory computer (PDP 11/10; Digital Equipment Corp., Maynard, Mass., USA).

The immunoglobulin containing cell number was expressed per millimetre mucosal length. ${ }^{13}$

Serum IgE was estimated by a solid phase radioimmunoassay and specific IgE milk antibodies by a radio-allergo-sorbent test (RC Aalberse, Central Laboratory of the Netherlands Red Cross Blood Transfusion Service, Amsterdam).

Statistical analysis was performed using Student's $t$ test.

\section{Results}

The histopathological findings in the patients with isolated proctitis were similar to those with ulcerative colitis. The infiltrate was mainly restricted to the mucosa. In seven patients with isolated proctitis an increased number of eosinophils was noticed and in nine patients the number of mast cells was increased. The degree of inflammation in most ulcerative colitis patients was more pronounced than in isolated proctitis.

Similarly, the number of IgA, IgG, and IgM containing cells per mm mucosa length resembled the findings in ulcerative colitis. The number of IgG containing cells correlated with the degree of activity of the disease. Sometimes a slight increase in the number of IgM containing cells was found (Fig. 1).

In the group of patients with isolated proctitis we compared the immunohistochemical findings in the rectal biopsy specimens taken at $7 \mathrm{~cm}$ from the anal margin with the findings in the biopsies taken more proximally from the distal sigmoid colon. The numbers of $\operatorname{IgA}, \operatorname{IgG}$, and IgM containing cells per $\mathrm{mm}$ mucosal length did not differ significantly in the two biopsy specimens. The number of IgE containing cells per $\mathrm{mm}$ mucosal length in the rectal 


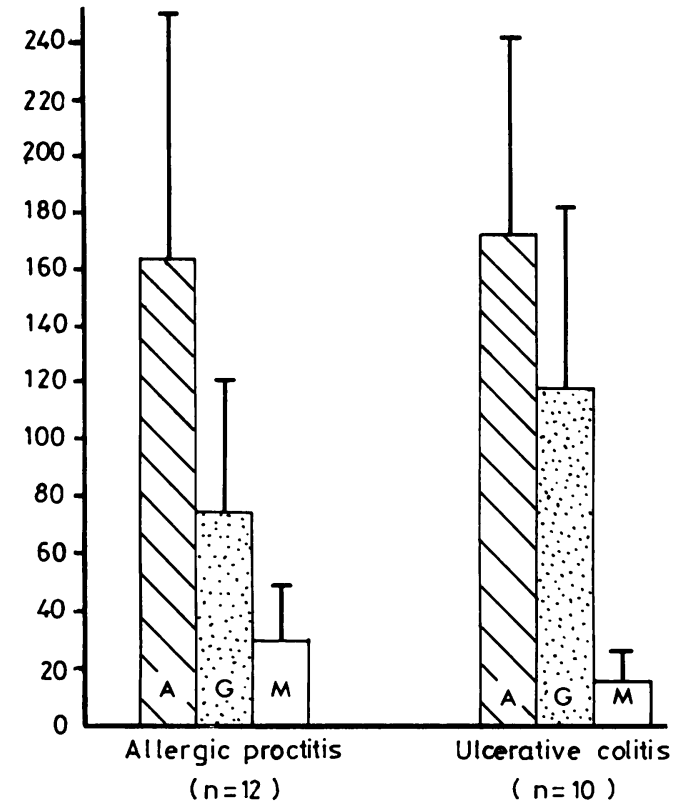

Fig. 1 Statistical analysis showed no significant difference between the number of immunoglobulin containing cells (IgA, $\operatorname{IgG}$ and $\operatorname{Ig} M)$ in rectal mucosa of patients with ulcerative colitis and allergic proctitis.

mucosa biopsy specimens was much higher than in the sigmoid colonic biopsy specimens, where the activity of inflammation was less (Fig. 2).

We compared the number of IgE containing cells in the rectal and sigmoid colonic mucosa obtained from the isolated proctitis patients with the results of immunohistochemical study in the three control groups (ulcerative colitis patients, patients with Crohn's disease of the colon, and patients without colitis). The number of IgE containing cells in the control groups was significantly lower than in the proctitis group for both rectal and sigmoid colonic biopsy specimens ( $\mathrm{P}<0.001$, Fig. 2$)$.

Eight of the 12 proctitis patients were treated with oral DSCG in a dose of $800 \mathrm{mg}$ daily for at least six weeks. All patients responded to DSCG. Disappearance or diminution of the daily blood loss was the most striking effect. The frequency of bowel motions changed only in two patients with diarrhoea (nos 7 and 8). There was no significant change in the haemoglobin, white cell count, or ESR during treatment.

All patients who used topical corticosteroids (nos. 1, 3, and 4) were able to stop this treatment.

Two patients (nos. 1 and 2) had a relapse of the proctitis two and four months after discontinuing DSCG therapy. After discontinuing therapy patient

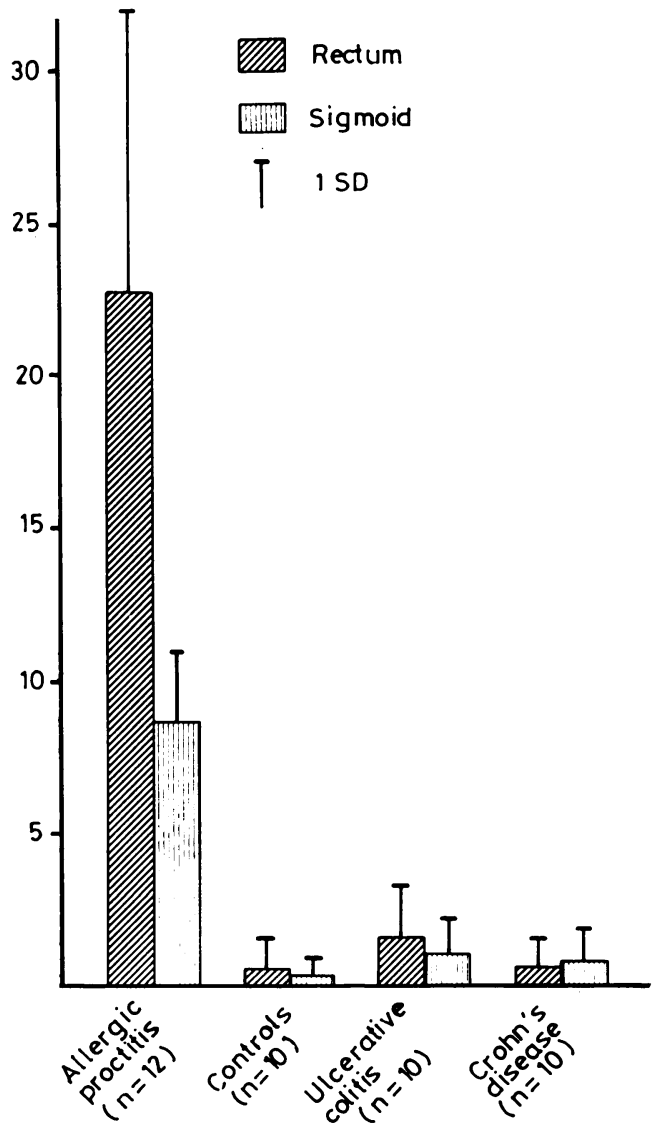

Fig. 2 Patients with allergic proctitis showed a statistically significant increased number of IgE containing cells in rectal and sigmoid colonic mucosa compared with controls and patients with ulcerative colitis and Crohn's disease (rectum: $\mathrm{P}<0.0001$, sigmoid: $\mathbf{P}<0.0001)$.

no. 1 needed a dose of $1600 \mathrm{mg}$ DSCG daily to achieve remission.

Four patients were examined endoscopically at least six weeks after starting DSCG treatment. In all these patients the endoscopic appearance was considerably improved, the ulcers had disappeared, and the rectal mucosa was normal or mild hyperaemia and oedema was seen in the distal part of the rectum (nos. 1, 2, 4, and 7). On histological examination of the mucosal biopsy specimens the acute inflammatory changes had disappeared (Fig. 3) The number of IgE containing cells per mm mucosal length did not differ significantly before and after DSCG treatment (Table 2) and showed no change with clinical response.

Values for the serum IgE varied between 20 

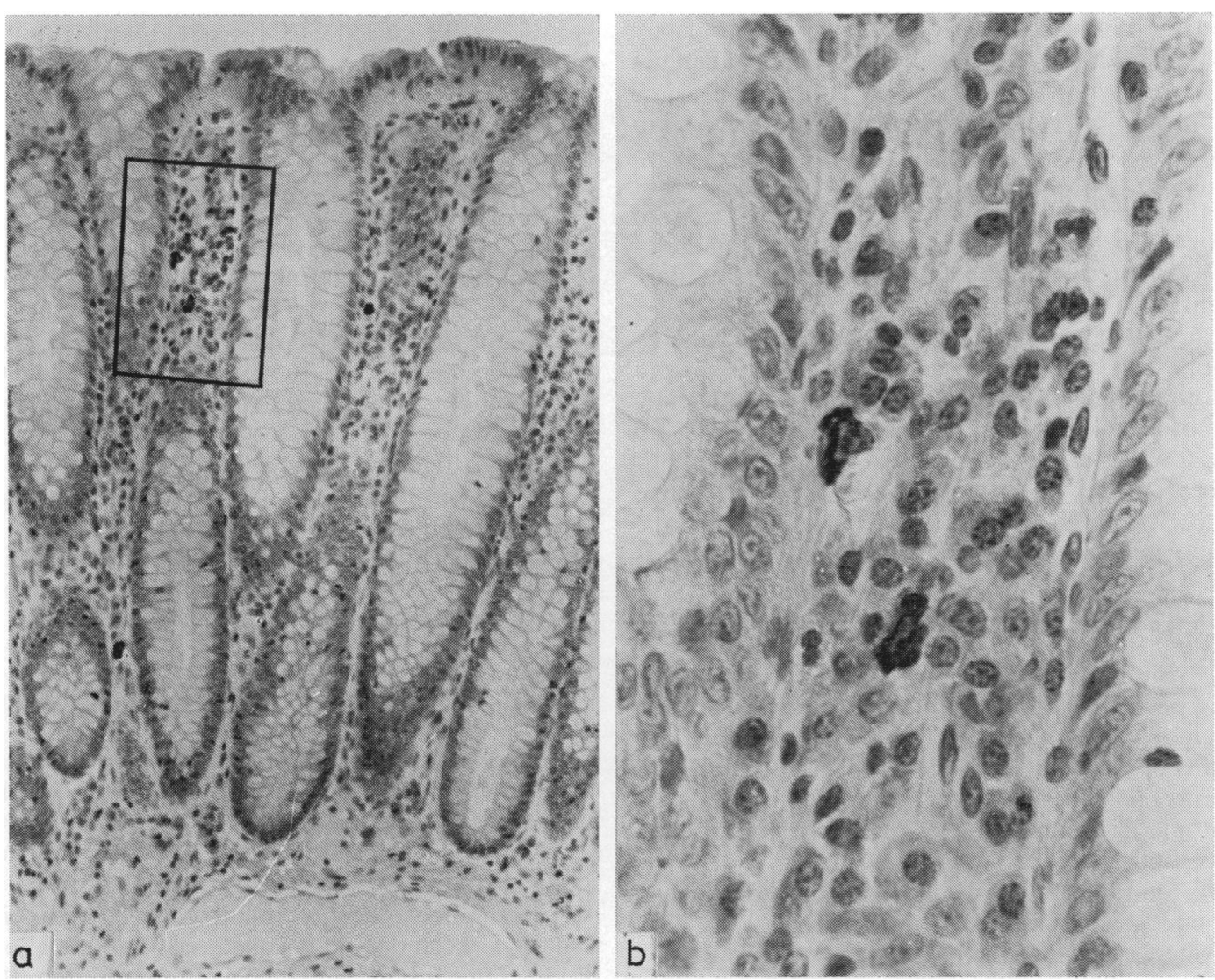

Fig. 3 (a) Four IgE containing cells in quiescent part of rectal mucosa in patient no. 7 with allergic proctitis. IgE peroxidase staining, $\times 120$. (b) High power view of (a). Two IgE containing cells. IgE peroxidase staining, $\times 600$.

and $192 \mathrm{ng} / \mathrm{ml}(95 \%$ of healthy controls $<500$ $\mathrm{ng} / \mathrm{ml})$. The RAST test for specific IgE milk antibodies was negative in all patients.

\section{Discussion}

The results of this study show that in the patients with isolated proctitis a group can be separated on clinical criteria (intermittent, benign course, limitation of inflammatory extent) and immunopathologi- cal findings (high numbers of IgE containing cells in rectal mucosa), a condition for which we suggest the name of 'allergic proctitis'.

In contrast with ulcerative colitis the course of the disease limited to the rectum is more benign; there are fewer complications, the absence of extracolonic manifestations is quite remarkable, spontaneous remissions are much more likely to occur, and the health of the patient is generally maintained.

Allergic proctitis is characterised by persistent or

Table 2 Endoscopic appearance of rectal mucosa and IgE containing cells per mm mucosal length in rectal biopsy specimens before and after six weeks DSCG treatment.

\begin{tabular}{|c|c|c|c|c|}
\hline \multirow[t]{2}{*}{ Patient no. } & \multicolumn{2}{|l|}{ Before DSCG } & \multicolumn{2}{|l|}{ After $D S C G$} \\
\hline & $\begin{array}{l}\text { Endoscopic } \\
\text { appearance }\end{array}$ & Rectum $(I g E / m m)$ & $\begin{array}{l}\text { Endoscopic } \\
\text { appearance }\end{array}$ & $\operatorname{Rectum}(I \mathrm{gE} / \mathrm{mm})$ \\
\hline $\begin{array}{l}1 \\
2 \\
4 \\
7\end{array}$ & $\begin{array}{l}\text { Superficial ulceration } \\
\text { Superficial ulceration } \\
\text { Ulcerations } \\
\text { Hyperaemia, oedema }\end{array}$ & $\begin{array}{l}31 \\
34 \\
35 \\
14\end{array}$ & $\begin{array}{l}\text { Hyperaemia, oedema } \\
\text { Normal } \\
\text { Hyperaemia, oedema } \\
\text { Normal }\end{array}$ & $\begin{array}{l}22 \\
20 \\
32 \\
17\end{array}$ \\
\hline
\end{tabular}


recurrent bloody mucous discharges. The stools are often formed, but occasionally loose, and sometimes associated with rectal tenesmus and urgency. The sigmoidoscopic picture is identical with that seen in ulcerative colitis, but the difference is in the sharp limitation of the inflammatory process to the level of the distal part of the sigmoid or below. In a mean follow-up period of more than seven years, none of the 12 patients we studied has developed a more extensive colitis.

Early reports claimed already that a food allergy factor was operative in ulcerative colitis ${ }^{28}$ and additional clinical observation led to a therapeutic trial of a milk-free diet. ${ }^{30} \mathrm{~A}$ subsequent relationship was found between high haemagglutinating antibodies to milk protein and relapses of ulcerative colitis. ${ }^{31}$ There has been no further support for the role of milk allergy in ulcerative colitis. No difference has been found between patients with ulcerative colitis and controls with respect to milk antibodies $^{17}$ and IgE specific antibodies to milk protein. ${ }^{32}$ Similarly, we were unable to demonstrate IgE specific antibodies to milk protein in our patients.

Only one patient had a personal history, while two patients had a family history of atopy. This incidence of atopic disorders is not as high as found by previous studies. ${ }^{32} 33$

We found large numbers of IgE containing cells in the rectal mucosa in patients with isolated proctitis, whereas normal rectal mucosa contains only a few of these cells. This confirms the findings of Heatley et al. ${ }^{14}$ In ulcerative colitis, however, contrary to the results of O'Donoghue and Kumar, ${ }^{34}$ we did not find increased numbers of IgE containing cells in rectal and colonic mucosal biopsy specimens.

Eight of the patients were treated with oral DSCG in a dose of $800 \mathrm{mg}$ daily. In all patients this treatment was effective. Heatley et al. ${ }^{20}$ were first to report this treatment in patients with proctitis. They used a dose of $700 \mathrm{mg}$ DSCG daily, partly given by enema and partly orally. Fourteen of the 26 patients responded to DSCG treatment, but there were no significant changes in rectal biopsy findings.

DSCG has also been investigated in ulcerative colitis. Mani et al. ${ }^{21}$ treated 12 patients for six months with $2 \mathrm{~g}$ of oral DSCG per day. These patients showed an improvement clinically, sigmoidoscopically, and on rectal biopsy. However, subsequent studies were less promising. ${ }^{22-24}$

Different pathogenetic mechanisms may account for the variable results of DSCG treatment in inflammatory bowel disease. As there is no direct evidence that IgE mediated hypersensitivity is involved in the pathogenesis of ulcerative colitis, it is conceivable that DSCG is not effective in this disorder.

Heatley et al. ${ }^{14}$ found that patients with an increased number of IgE containing cells with an excess of eosinophils in the rectal mucosa showed clinical improvement on DSCG. This suggests that a hypersensitivity reaction, mediated by $\operatorname{IgE}$, is important in the pathogenesis of allergic proctitis. It is of interest that DSCG treatment does not affect the number of IgE containing cells in the mucosa of the rectum and the sigmoid colon. This is in keeping with the mode of action of DSCG, which inhibits the release of chemical mediators such as histamine and does not influence IgE antibody formation. ${ }^{35}$

The pathogenesis of this disease is still unknown. One explanation might be that antigens present in the faeces are responsible for the inflammatory process in the bowel wall at the site of maximum faecal stasis, the rectum.

We gratefully acknowledge help from many people who made it possible to conduct the study: Dr C Cornelisse and Mrs A van der Zon for morphometric analysis, Dr J Hermans for statistical analysis, Mrs $M$ van der Zee-Berkhout for administrative help, Fisons Limited, Pharmaceutical Division, for supplying the disodium cromoglycate and Dr R C Aalberse, Department of Immunochemistry of the Central Laboratory of the Netherlands Red Cross Blood Transfusion Service, Amsterdam, for the analysis of serum IgE and specific IgE milk antibodies.

\section{References}

${ }^{1}$ Lennard-Jones JE, Cooper GW, Newell AC, Wilson CWE, Avery Jones F. Observations on idiopathic proctitis. Gut 1962; 3: 201-6.

${ }^{2}$ Nugent FW, Veidenheimer MC, Zuberi S, Garabedian MM, Parikh NK. Clinical course of ulcerative proctosigmoiditis. Dig Dis 1970; 15: 321-6.

${ }^{3}$ Powell-Tuck J, Ritchie JK, Lennard-Jones JE. The prognosis of idiopathic proctitis. Scand J Gastroenterol 1977; 12: 727-32.

${ }^{4}$ Folley JH. Ulcerative proctitis. $N$ Engl J Med 1970; 282: 1362-4.

${ }^{5}$ Lockhart Mummery P. The varieties of colitis and their diagnosis by sigmoidoscopic examination. $\mathrm{Br}$ Med $\mathrm{J}$ 1911; 2: 1685-6.

${ }^{6}$ Brooke BN. What is ulcerative colitis? Lancet 1953; 1: $1220-5$.

${ }^{7}$ Goligher JC. What is ulcerative colitis? Lancet (letter) 1953; 2: 38.

${ }^{8}$ Rice-Oxley JM. What is ulcerative colitis? Lancet (letter) 1953; 2: 38 . 
${ }^{9}$ Crabbé PA, Heremens JF. The distribution of immunoglobulin containing cells along the human gastrointestinal tract. Gastroenterology 1966; 51 : 305-16.

${ }^{10}$ Gelzayd EA, Kraft SC, Fitch FW, Kirsner JB. Distribution of immunoglobulins in human mucosa. II Ulcerative colitis and abnormal mucosal control subjects. Gastroenterology 1968; 54: 341-7.

${ }^{11}$ Söltoft J, Binder V, Gudmand-Höyer E. Intestinal immunoglobulins in ulcerative colitis. Scand $J$ Gastroenterol 1973; 8: 293-300.

${ }^{12}$ Baklien $\mathrm{K}$, Brandtzaeg P. Immunohistochemical characterization of local immunoglobulin formation in Crohn's disease of the ileum. Scand $J$ Gastroenterol 1976; 11 : 447-57.

${ }^{13}$ Rosekrans PCM, Meijer CJLM, van der Wal AM, Cornelisse CJ, Lindeman J. Immunoglobulin-containing cells in inflammatory bowel disease. Gut 1980;21:941-7.

${ }^{14}$ Heatley RV, Calcraft BJ, Fifield R, Rhodes J, Whitehead RH, Newcombe RG. Immunoglobulin $\mathrm{E}$ in rectal mucosa of patients with proctitis. Lancet 1975; 2: 1010-2.

${ }^{15}$ Das KM, Erber WF, Rubinstein A. Immunohistochemical changes in morphologically involved and uninvolved mucosa of patients with idiopathic proctitis. J Clin Invest 1977; 59: 379-85.

${ }^{16}$ Wright R, Truelove SC. A controlled therapeutic trial of various diets in ulcerative colitis. Br Med J 1965; 2: $138-41$.

${ }^{17}$ Jewell DP, Truelove SC. Circulating antibodies to cow's milk proteins in ulcerative colitis. Gut 1972; 13: 796-801.

${ }^{18}$ Wright R, Truelove SC. Circulating and tissue eosinophils in ulcerative colitis. Am J Dig Dis 1966; 2: 831-46.

${ }^{19}$ Heatley RV, James PD. Eosinophils in rectal mucosa. Gut 1978; 20: 787-91.

${ }^{20}$ Heatley RV, Calcraft BJ, Rhodes J, Owen E, Evans BK. Disodium cromoglycate in the treatment of chronic proctitis. Gut 1975; 16: 559-63.

${ }^{21}$ Mani V, Green FHY, Lloyd G, Fox H. Treatment of ulcerative colitis with oral disodium cromoglycate. Lancet 1976; 1 : 439-41.

${ }^{22}$ Dronfield MW, Langman MJS. Controlled comparison of sodium cromoglycate and sulphasalazine in the maintenance of remission in ulcerative colitis. Gut 1977; 18: A973.

${ }^{23}$ Gould SR, Buckell NA, Day DW, Edwards AM, Lennard-Jones JE. Controlled trial of disodium cromoglycate in chronic persistent colitis. Gut 1978; 19: A444.

${ }^{24}$ Willoughby CP, Heyworth MF, Piris J, Truelove SC. Comparison of D.S.C.G. and sulphasalazine as maintenance therapy for ulcerative colitis. Lancet 1979 ; 1: 119-22.

${ }^{25}$ Morson BC, Dawson IMP. Gastrointestinal pathology, Oxford: Blackwell Scientific Publications; 512-74.

${ }^{26}$ Bosman FT, Lindeman J, Kuiper G, van der Wal A, Kreuning $J$. The influence of fixation on immunoperoxidase staining of plasma cells in paraffin sections of intestinal biopsy specimens. Histochemistry 1977; 53: 57-62.

${ }^{27}$ Rosekrans PCM, Meijer CJLM, Cornelisse CJ, vd Wal AM, Lindeman J. Use of morphometry and immunohistochemistry of small intestinal biopsy specimens in the diagnosis of food allergy. J Clin Pathol 1980; 33: 125-30.

${ }^{28}$ Andressen AFR. Ulcerative colitis. An allergic phenomenon. Am J Dig Dis 1941; 9: 91-8.

${ }^{29}$ Rowe AH. Chronic ulcerative colitis-allergy in its etiology. Ann Intern Med 1942; 17: 83-100.

${ }^{30}$ Truelove SC. Ulcerative colitis provoked by milk. Br Med J 1961; 1: 154-60.

${ }^{31}$ Wright $\mathrm{R}$, Truelove SC. Circulating antibodies to dietary proteins in ulcerative colitis. $\mathrm{Br}$ Med $J$ 1965; 2: 142-44.

${ }^{32}$ Jewell DP, Truelove SC. Reaginic hypersensitivity in ulcerative colitis. Gut 1972; 13: 903-6.

${ }^{33}$ Mee AS, Brown D, Jewell DP. Atopy in inflammatory bowel disease. Scand J Gastroenterol 1979; 14: 743-6.

${ }^{34}$ O'Donoghue DP, Kumar P. Rectal IgE cells in inflammatory bowel disease. Gut 1979; 20: 149-53.

${ }^{35}$ Cox JG. Disodium cromoglycate. Mode of action and its possible relevance to the clinical use of the drug. Br J Dis Chest 1971; 65: 189-204. 